\title{
Pengaruh Terapi Musik Terhadap Penurunan Tingkat Depresi Pasien Stroke Non Hemoragik di RSUP NTB dan RSI Siti Hajar Mataram
}

\author{
DEWI PURNAMAWATI DAN AINUN SAJIDAH \\ Pengajar Polteks Kemenkes Mataram
}

\begin{abstract}
Stroke is the loss of brain function caused by the cessation of blood supply to the brain. Stroke may be accompanied by depression as a comorbidity that can inhibit the healing process, so that needs to be handling.

The purpose of this research is to determine the effect of music therapy to decrease levels of depression non hemorrhagic stroke patients. Design used in this study is Pra Experimental with one group pretest-posttest approach. The study population are all stroke patients who underwent treatment at RSUP Nusa Tenggara Barat and RSI Siti Hajar during the period of data collection. The samples of this study are non hemorrhagic stroke patients with awareness compos mentis and willing to become respondents. The number of samples is 21 people. The sampling technique is accidental sampling. Non hemorrhagic stroke patients are given treatment to listening to music twice a day in the morning and evening for 15 - 30 minutes within 1 week ( 7 days). Then evaluated after music therapy on day 7. Data collection using observation sheet to assess depression score from Depression Beck Inventory. The result of statistic analysis summarized that there are influence of music therapy to decrease levels of depression non hemorrhagic stroke patients $(p=0,01$, alpha $=0,05)$.

Based on the result of this study, recommended to policy makers to facilitate the provision of music therapy program at special care room of stroke patients so that they can do music therapy program simultaneously. And also, expected to nurse to motivate patients to actively participate to implement music therapy during treatment in hospital and at home.
\end{abstract}

Keyword: Music therapy, depression, Non Haemorrhagic Stroke.

\section{LATAR BELAKANG}

Salah satu penyakit yang sering muncul dan seringkali merupakan kulminasi pada penyakit serebrovaskuler selama beberapa tahun adalah stroke (Smeltzer, 2001). Hampir tiga perempat serangan stroke adalah Stroke Non Hemoragik (SNH) yang disebabkan oleh obstruksi vaskular, dan sekitar seperempat kasus stroke adalah hemoragik yang diakibatkan oleh rupturnya aneurisme, dan vaskular hipertensif (Hudak \& Gallo, 1997). Stroke memiliki prevalensi yang cukup tinggi dan merupakan masalah neurologik primer di dunia karena meningkatkan angka mortalitas dan morbiditas, meskipun upaya pencegahan telah menimbulkan penurunan insiden dalam beberapa tahun terakhir. Serangan stroke menimbulkan dampak morbiditas dan kecacatan yang cukup tinggi. Terdapat sekitar 2 juta orang yang bertahan hidup dari stroke mempunyai beberapa kecacatan dan $40 \%$ diantaranya memerlukan bantuan dalam aktivitas sehari-hari (Smeltzer \& Bare, 2001). Depkes, (2007) menyebutkan stroke termasuk golongan penyakit pembuluh darah sebagai 3 penyakit terbesar di Indonesia. Di Rumah Sakit Provinsi NTB berdasarkan data Instalasi Rekam Medik tercatat jumlah pasien yang dirawat inap tahun 2006 sebanyak 110 orang dengan kasus stroke dan 44 orang ( $40 \%$ ) meninggal, tahun 2007 sejumlah 95 kasus stroke dan meninggal 47 orang $(60 \%)$ dan tahun 2008 kasus stroke sejumlah 77 dan 54 orang $(57 \%)$ meninggal. 
Menurut Martina, (2009) sekitar 30-50 persen penderita stroke mengalami gangguan suasana perasaan hati/mood atau depresi yang dapat disebabkan terganggunya sistem limbik dari otak, yaitu bagian otak di bawah cortex (bagian otak luar), yang bertanggung jawab terhadap aspek emosi. Berbagai studi tentang depresi pada pasien stroke juga memperlihatkan angka prevalensi 27-45 persen.

Menurut Suryo, (2008) depresi dapat disebabkan karena rusaknya jaringan otak atau akibat dari ketidakmampuan bergerak atau berbicara, hilangnya kemandirian, rasa percaya diri, peran sosial, maupun pekerjaan, dan dampak depresi pada penderita stroke bisa menghambat proses penyembuhan dan pulihnya fungsi anggota tubuh yang terganggu. Depresi dapat sebagai komorbiditas dan melemahkan daya tahan, meningkatkan kesakitan, hingga memicu kematian lebih tinggi serta memicu peluang stroke kedua lebih besar hingga dua kali lipat sehingga dapat menjadi penyulit dan meningkatkan ketidakpatuhan terhadap terapi (Suryo, 2008). Penelitian Asmawati (2007) menyebutkan kejadian depresi pada penderita stroke yang datang ke Poli Syaraf Rumah Sakit Umum Mataram mencapai $49 \%$.

Manifestasi klinis yang muncul pada pasien stroke diantaranya adalah nyeri, defisit motorik, verbal dan emosional dimana emosi pasien sering kali labil, mudah depresi dan bingung (Potter \& Perry, 2005). Sedangkan pengobatan untuk stroke dan depresi meliputi penatalaksanaan farmakologis dan non farmakologis. Namun pengobatan farmakologis dalam jangka waktu lama dapat menimbulkan beberapa efek samping yang merugikan pasien dan risiko interaksi antara obat untuk kedua penyakit. sehingga, pengobatannya pun harus dilakukan oleh tim terpadu, seperti ahli jantung, ahli jiwa, dan terapis sosial. Oleh sebab itu terapi non farmakologis sangat dianjurkan yaitu pengendalian faktor risiko dan manajemen stres yang dapat dilakukan melalui terapi musik.

Dalam bidang kedokteran, terapi musik dikenal sebagai complementary medicine yang dapat digunakan untuk meningkatkan, mempertahankan dan mengembalikan kesehatan fisik, mental, emosional maupun spiritual dengan menggunakan bunyi atau irama tertentu. Terapi musik secara medis dan ilmiah terbukti sebagai alat efektif dalam rehabilitasi setelah stroke dengan manfaat diantaranya mengendalikan, meningkatkan mood dan motivasi (Stroke Association, 2008).

Beberapa penelitian telah membuktikan terapi musik dapat menurunkan keluhan fisik maupun mental. Clive Robbins, (2008) mengatakan pada tingkat non verbal, musik mengaktifkan pikiran, mengintegrasikan perhatian/ konsentrasi, dan sepertinya membantu meregulasi beberapa fungsi tubuh. Peneliti sendiri telah mengadakan studi pendahuluan di Ruang 28 IRNA II RSSA (Rumah Sakit Syaiful Anwar) Malang dan mendapatkan bahwa dosis harian musik selama 2 kali 15-20 menit selama 1 minggu telah dapat menurunkan tingkat depresi pada pasien stroke. Sedangkan untuk pemilihan jenis musik untuk terapi musik dapat disesuaikan dengan keinginan pasien dan kebutuhannya secara individual (American Music Therapy Association, 2009).

Berdasarkan uraian di atas serta relevansi yang erat antara terapi musik dengan penurunan depresi yang menyertai stroke, maka perlu dilakukan suatu penelitian untuk mengetahui pengaruh terapi musik terhadap penurunan depresi pada pasien stroke.

\section{METODE}

Penelitian ini menggunakan desain Pra Experimental dengan pendekatan one group pretest-posttest. Tehnik pengambilan sampel menggunakan Accidental Sampling dengan kriteria inklusi sampel adalah pasien stroke non hemoragik, kesadaran compos mentis, tidak mengalami gangguan pendengaran, bersedia menjadi responden, dan dirawat oleh dokter yang sama. Kelemahan penelitian ini adalah tidak dikendalikannya faktor obat antidepresan pada sampel penelitian ini.

Penelitian ini dilaksanakan di RSUP NTB dan di Rumah Sakit Islam Siti Hajar Mataram. Penelitian ini dilaksanakan mulai September 2013 sampai dengan Januari 2014. Sampel penelitian ini berjumlah 21 responden.

Penelitian ini menggunakan instrumen berupa kuesioner untuk mendapatkan data usia, jenis kelamin, frekuensi serangan stroke dan menggunakan pedoman wawancara daftar inventaris Beck/skala Depresi Beck untuk menilai tingkat depresi responden (skala ordinal). Data dikumpulkan oleh 
peneliti dan kolektor data. Setelah penentuan responden, dilakukan penilaian depresi, kemudian diberikan terapi musik selama 1530 menit pada pagi dan sore hari selama 7 hari berturut-turut. Setelah 7 hari tindakan, dilakukan penilaian kembali tingkat depresi. Adapun jenis musik yang diberikan adalah sesuai dengan keinginan pasien, musik yang disiapkan umumnya dengan irama yang tidak menghentak, jenis musik instrumentalia dan murottal(al Qur'an).

Etika penelitian tetap dipertahankan selama penelitian diantaranya hak dan kerahasiaan pasien tetap dijaga dengan hanya mencantumkan nomor kode. Apabila selama pelaksanaan penelitian pasien tidak bersedia terlibat dalam penelitian maka responden berhak untuk mengundurkan diri. Selama penelitian berlangsung, peneliti tetap memperhatikan tingkat kelelahan pasien.

\section{HASIL PENELITIAN}

Hasil penelitian terdiri dari karakteristik responden meliputi umur, jenis kelamin, tingkat depresi sebelum dilakukan intervensi, tingkat depresi setelah dilakukan intervensi, serta pengaruh terapi musik terhadap tingkat depresi.

\section{A. HASIL PENELITIAN}

\section{Karakteristik umum responden}

a. Distribusi responden berdasarkan jenis kelamin dan serangan stroke Untuk melihat distribusi responden berdasarkan jenis kelamin dan serangan stroke dapat dilihat pada tabel 1 berikut ini:

Tabel 1: Distribusi responden stroke yang mengalami depresi berdasarkan jenis kelamin dan serangan stroke di RSUP NTB dan RSI Siti Hajar Mataram.

\begin{tabular}{|l|c|c|c|c|c|c|}
\hline \multirow{2}{*}{$\begin{array}{l}\text { Jenis } \\
\text { kelamin }\end{array}$} & \multicolumn{4}{|c|}{ Serangan } & \multicolumn{2}{|c|}{ Total } \\
\cline { 2 - 7 } & Serangan 1 & $\%$ & Serangan 2 & $\%$ & Frek & $\%$ \\
\hline Laki-laki & 6 & 54,5 & 5 & 45,5 & 11 & 100 \\
\hline Perempuan & 10 & 100 & 0 & 0 & 10 & 100 \\
\hline Total & 16 & 76,2 & 5 & 23,8 & 21 & 100 \\
\hline
\end{tabular}

Berdasarkan tabel diatas didapatkan ada sebanyak 6 dari $11(54,5 \%)$ responden berjenis kelamin laki-laki mengalami serangan pertama stroke dan ada sebanyak 10 dari $10(100 \%)$ responden berjenis kelamin perempuan mengalami serangan pertama stroke.

a. Distribusi responden berdasarkan umur dan serangan stroke

Tabel 2 di bawah ini menjelaskan distribusi responden berdasarkan umur dan serangan stroke.

Tabel 2 : Distribusi responden stroke yang mengalami depresi berdasarkan umur dan serangan stroke di RSUP NTB dan RSI Siti Hajar Mataram

\begin{tabular}{|c|c|c|c|c|c|c|}
\hline \multirow{2}{*}{ Umur } & \multicolumn{4}{|c|}{ Serangan } & \multicolumn{2}{|c|}{ Total } \\
\cline { 2 - 7 } & Serangan 1 & $\%$ & Serangan 2 & $\%$ & Frek & $\%$ \\
\hline$<40$ tahun & 1 & 100 & 0 & 0 & 1 & 100 \\
\hline $40-60$ tahun & 12 & 80 & 3 & 20 & 15 & 100 \\
\hline$>60$ tahun & 3 & 60 & 2 & 40 & 5 & 100 \\
\hline Total & 16 & 76,2 & 5 & 23,8 & 21 & 100 \\
\hline
\end{tabular}

Berdasarkan tabel diatas didapatkan terdapat 1 responden yang berumur kurang dari 40 tahun mengalami stroke serangan pertama, ada sebanyak 12 dari $15(80 \%)$ responden yang berumur $40-60$ tahun mengalami stroke serangan pertama dan ada 3 dari $5(60 \%)$ responden yang berumur $>60$ tahun mengalami stroke serangan pertama.

a. Distribusi responden berdasarkan frekuensi serangan dan tingkat depresi sebelum terapi musik

Distribusi responden berdasarkan frekuensi serangan dan tingkat depresi sebelum terapi music dapat dilihat pada table berikut ini:

Tabel 3: Distribusi responden stroke yang mengalami depresi berdasarkan frekuensi serangan dan tingkat depresi sebelum dilakukan terapi musik di RSUPNTB dan RSI Siti Hajar Mataram

\begin{tabular}{|c|c|c|c|c|}
\hline Tingkat Depresi & \multicolumn{4}{|c|}{ Serangan } \\
\cline { 2 - 5 } Pre Terapi Musik & Serangan 1 & $\%$ & Serangan 2 & $\%$ \\
\hline Ringan & 1 & 4.8 & 0 & 0 \\
\hline Sedang & 3 & 14,2 & 0 & 0 \\
\hline Berat & 12 & 81,0 & 5 & 100 \\
\hline Total & 16 & 100 & 5 & 100 \\
\hline
\end{tabular}

Berdasarkan tabel diatas menunjukkan bahwa sebelum dilakukan terapi musik ada sebanyak 12 dari $16(81 \%)$ responden stroke serangan pertama mengalami depresi berat, dan ada sebanyak 5 dari $5(100 \%)$ responden stroke serangan kedua mengalami depresi berat. 
a. Distribusi responden berdasarkan frekuensi serangan dan tingkat depresi sesudah terapi musik

Tabel 4 berikut ini akan menggambarkan distribusi responden berdasarkan frekuensi serangan dan tingkat depresi sesudah dilakukan terapi musik.

Tabel 4: Distribusi responden stroke yang mengalami depresi berdasarkan frekuensi serangan dan tingkat depresi sesudah dilakukan terapi musik di RSUP NTB dan RSI Siti Hajar Mataram

\begin{tabular}{|c|c|c|c|c|}
\hline \multirow{2}{*}{$\begin{array}{l}\text { Tingkat Depresi } \\
\text { sesudah terapi } \\
\text { musik }\end{array}$} & \multicolumn{4}{|c|}{ Serangan } \\
\hline & Serangan 1 & $\%$ & Serangan 2 & $\%$ \\
\hline Normal & 5 & 33,25 & 0 & 0 \\
\hline Ringan & 5 & 33,25 & 1 & 20 \\
\hline Sedang & 4 & 25,0 & 1 & 20 \\
\hline Berat & 2 & 12,5 & 3 & 60 \\
\hline Total & 16 & 100 & 5 & 100 \\
\hline
\end{tabular}

Berdasarkan tabel diatas menunjukkan bahwa setelah dilakukan terapi musik ada sebanyak 2 dari $16(12,5 \%)$ responden stroke serangan pertama mengalami depresi berat, 4 dari 16(25\%) mengalami depresi sedang, dan ada masing-masing 5 dari $16 \quad(33,25 \%)$ responden yang mengalami depresi ringan dan tidak mengalami depresi. Sedangkan pada responden stroke serangan kedua, ada sebanyak 3 dari $5(60 \%)$ responden mengalami depresi berat, dan masing-masing 1 dari 5 responden $(20 \%)$ mengalami depresi sedang dan depresi ringan.

\section{Tingkat depresi sebelum dan sesudah dilakukan terapi musik}

Tingkat depresi sebelum dan sesudah dilakukan terapi musik dapat dilihat pada tabel 5 dibawah ini.

Tabel 5: Distribusi responden berdasarkan tingkat depresi sebelum dan sesudah dilakukan terapi musik di RSUP NTB dan RSI Siti Hajar Mataram

\begin{tabular}{|c|c|c|c|c|}
\hline \multirow{2}{*}{ Tingkat Depresi } & \multicolumn{4}{|c|}{ Terapi Musik } \\
\cline { 2 - 5 } & $\begin{array}{c}\text { Sebelum } \\
\text { tindakan }\end{array}$ & $\%$ & $\begin{array}{c}\text { Sesudah } \\
\text { tindakan }\end{array}$ & $\%$ \\
\hline Normal & - & - & 5 & 23,8 \\
\hline Ringan & 1 & 4.8 & 6 & 28,6 \\
\hline Sedang & 3 & 14,2 & 5 & 23,8 \\
\hline Berat & 17 & 81,0 & 5 & 23,8 \\
\hline Total & 21 & 100 & 21 & 100 \\
\hline
\end{tabular}

Berdasarkan tabel 5 diatas diperoleh tingkat depresi sebelum dilakukan terapi musik nilai terkecil adalah tingkat depresi ringan sebanyak 1 responden $(4,8 \%)$ dan terbanyak adalah tingkat depresi berat sebanyak 12 responden (81\%). Sedangkan setelah dilakukan terapi musik diperoleh tingkat depresi responden tersebar merata dari normal (tidak depresi), depresi sedang dan depresi berat masing-masing 5 responden $(23,8 \%)$ dan sebanyak 6 responden $(28,6 \%)$ berada pada tingkat depresi ringan.

\section{Pengaruh terapi musik terhadap penurunan depresi pada pasien stroke non hemoragik}

Setelah dilakukan uji statistik lanjut menggunakan Wilcoxon Signed Rank Test dengan bantuan komputer, diperoleh nilai p Value $=0,001($ alpha $=0,05)$ maka dapat disimpulkan bahwa ada pengaruh terapi musik terhadap penurunan tingkat depresi pada pasien stroke non hemoragik.

\section{PEMBAHASAN}

Hasil penelitian ini membuktikan bahwa ada pengaruh terapi musik terhadap penurunan tingkat depresi pada pasien stroke non hemoragik. Hasil penelitian secara lengkap akan dibahas sebagai berikut:

Analisis univariat hasil penelitian ini menunjukkan responden terbanyak berusia antara usia $40-60$ tahun $(71,4 \%)$. Hal ini menunjukkan usia tua lebih berisiko terjadi stroke karena stroke dapat timbul akibat aterosklerosis dan kerentanan terhadap ateroskelerosis koroner meningkat dengan bertambahnya usia. Namun, meskipun penyempitan lumen terjadi progresif dan kemampuan respon vaskular berkurang manifestasi klinis belum tampak sampai proses aterogenik tahap lanjut. Fase preklinis ini berlangsung sekitar 20-40 tahun, sehingga penyakit yang serius jarang terjadi sebelum usia 40 tahun (Sylvia A. Price\& Lorraine Wilson,1994). Hasil penelitian ini menunjukkan bahwa ada 1 orang responden berusia kurang dari 40 tahun mengalami serangan stroke non hemoragik, artinya telah terjadi pergeseran usia serangan stroke. 
Hasil penelitian ini juga menunjukkan bahwa responden terbanyak merupakan responden dengan serangan pertama stroke sebanyak 16 responden $(76,2 \%)$, dan terdapat 5 responden $(23,8 \%)$ mengalami serangan kedua. Hasil ini menunjukkan bahwa risiko untuk terjadinya serangan stroke berulang merupakan hal yang harus diwaspadai oleh penderita hipertensi atau penderita yang pertama mengalami serangan stroke. Serangan stroke berulang dapat berakibat fatal dan mengakibatkan kualitas hidup yang lebih buruk dari pada serangan pertama. Hal ini didukung oleh data menurut Smeltzer \& Bare, (2001) stroke adalah penyakit peringkat ketiga sebagai penyebab kematian dengan laju mortalitas $18-37 \%$ untuk stroke pertama dan $62 \%$ untuk stroke pada serangan berikutnya. Menurut Suryo, (2008) depresi dapat disebabkan karena rusaknya jaringan otak atau akibat dari ketidakmampuan bergerak atau berbicara, hilangnya kemandirian, rasa percaya diri, peran sosial, maupun pekerjaan, dan dampak depresi pada penderita stroke bisa menghambat proses penyembuhan dan pulihnya fungsi anggota tubuh yang terganggu. Depresi dapat sebagai komorbiditas dan melemahkan daya tahan, meningkatkan kesakitan, hingga memicu kematian lebih tinggi serta memicu peluang stroke kedua lebih besar hingga dua kali lipat sehingga dapat menjadi penyulit dan meningkatkan ketidakpatuhan terhadap terapi (Suryo, 2008).

Kondisi depresi yang menjadi lebih baik atau lebih buruk setelah dilakukan terapi musik tidak hanya dipengaruhi oleh adanya terapi musik tetapi dipengaruhi oleh beberapa faktor yang lain seperti adanya terapi dengan antidepresan dan lokasi lesi yang dialami pasien. Dari penelitian terhadap pasien pascastroke didapatkan bahwa sekitar $44 \%$ pasien dengan lesi di korteks kiri mengalami depresi sedangkan pada pasien dengan lesi di subkorteks kiri 39\%. Depresi pada lesi di korteks kanan $11 \%$ dan di subkorteks kanan $14 \%$. Tidak terdapat perbedaan kejadian depresi yang bermakna antara lesi di korteks dengan subkorteks. Tetapi prevalensi depresi lebih tinggi secara bermakna pada lesi di hemisfer kiri dibandingkan dengan lesi di hemisfer kanan (Nurmiati Amir, dalam Cermin Dunia Kedokteran no 149, 2005).
Hasil penelitian menyimpulkan bahwa ada pengaruh terapi musik terhadap penurunan depresi pada pasien stroke non hemoragik $(\mathrm{p}=$ 0,001 ; alpha $=0.05$ ). Hasil penelitian ini didukung oleh teori yang mengatakan bahwa terapi musik dikenal sebagai complementary medicine yang dapat digunakan untuk meningkatkan, mempertahankan dan mengembalikan kesehatan fisik, mental, emosional maupun spiritual dengan menggunakan bunyi atau irama tertentu. Terapi musik secara medis dan ilmiah terbukti sebagai alat efektif dalam rehabilitasi setelah stroke dengan manfaat diantaranya mengendalikan, meningkatkan mood dan motivasi (Stroke Association, 2008).

Beberapa penelitian telah membuktikan terapi musik dapat menurunkan keluhan fisik maupun mental. Clive Robbins, (2008) mengatakan pada tingkat non verbal, musik mengaktifkan pikiran, mengintegrasikan perhatian/ konsentrasi, dan sepertinya membantu meregulasi beberapa fungsi tubuh. Penelitian oleh Sarkamo di Helsinki menunjukkan setelah 3 bulan pasien pasca stroke diterapi dengan musik terdapat peningkatan memori verbal kelompok musik $60 \%$. Pada tahun 1996, peneliti dari Universitas Colorado memberikan pasien stroke 30 menit stimulasi ritmik setiap hari selama 3 minggu dan hasilnya menunjukkan perbaikan yang signifikan dari kemampuan mereka untuk berjalan dengan mantap (Emaxhealth, 2008). Beberapa studi lain menyimpulkan ada korelasi positif antara terapi musik dengan peningkatan status klinis pasien depresi (Maratos, 2008).

\section{SIMPULAN DAN SARAN}

Hasil penelitian ini menyimpulkan bahwa responden stroke yang mengalami depresi terbanyak berjenis kelamin laki-laki, berumur antara 40 - 60 tahun, dan merupakan pasien stroke serangan pertama. Penelitian ini juga menyimpulkan bahwa terapi musik memiliki pengaruh signifikan terhadap penurunan depresi pada pasien stroke non hemoragik $(\mathrm{p}=$ $0,001$; alpha $=0,05)$.

Berdasarkan hasil penelitian ini disarankan agar penentu kebijakan/manager perawat membuat Standar Asuhan Keperawatan dan menyediakan program pendidikan kesehatan, dan ruangan khusus untuk perawatan pasien 

mengidentifikasi adanya depresi yang dialami pasien pasca stroke. Perawat memotivasi pasien untuk terlibat dan aktif berperan serta dalam melakukan terapi musik selama perawatan pasca stroke baik dirumah sakit maupun setelah dilakukan perawatan dirumah.

\section{KEPUSTAKAAN}

Dinas Kesehatan Propinsi NTB.2007. Hasil Riskesdas Propinsi 2007. Hasil Riskesdas Propinsi NTB Tahun 2007.file pdf.diakses 8 September 2009

Maratos AS, et al. 2008.Music therapy for depression (Review). Cochrane Database of Systematic Reviews.Jurnal reference

Martina.2001. Penanganan Depresi Pasca Stroke.http://www.Kompas.com. diakses 6 Juni 2009

Nurmiati Amir, 2005. Cermin Dunia Kedokteran, No 149. Diambil dari http://www. Pada tanggal 4 Januari 2010

Hudak \& Gallo. 1997. Keperawatan Kritis Vol. 2, EGC, Jakarta.

Pandoe, Wing., 2006. Musik Terapi, hhtp//www.my.opera.com/paw, diakses 5 Juni 2009.

Potter, Patricia A; Anne Griffin Perry. 1997. Buku Ajar Fundamental Keperawatan: Konsep, Proses, dan Praktik Edisi 4 Volume 2.EGC. Jakarta.

Smeltzer, Suzanne C. dan Bare, Brenda G. 2002. Buku Ajar Keperawatan Medikal Bedah Brunner \& Suddarth. Ed. 8. Cetakan I. EGC. Jakarta

Setiadi, 2007. Konsep dan Penulisan Riset Keperawatan, Ed. I, Cetakan I, Graha Ilmu, Yogyakarta.

Silvia, Rizki.Terapi Musik.2009. http//forum.psikologi.ugm.ac.id. diakses 9 Juni 2009

Sandra L Siedlecki. Effect of music on power, pain, depression and disability., Cleveland Clinic Foundation, Ohio, and Marion Good, Case Western University, Ohio. Journal of Advanced Nursing. Volume 54.5 , pages 553 to 562 .
stroke sehingga dapat diberikan terapi musik secara kontinue pada pasien. Perawat hendaknya melakukan pengkajian secara komprehensif terhadap pasien stroke untuk

\author{
Suryo.2008. Komorbiditas Depresi Pada \\ Jantung Iskemik dan Stroke. \\ http.www.medicastore.com. diakses 6 \\ Juni 2009.
}

